European Journal of Adapted Physical Activity, 1(1), 9-21

(C) European Federation of Adapted Physical Activity, 2008

\title{
ATHLETIC IDENTITY AND SELF-ESTEEM IN FLEMISH ATHLETES WITH A DISABILITY
}

\author{
Peter Van de Vliet ${ }^{1}$, Debbie Van Biesen, Yves C. Vanlandewijck \\ Department of Rehabilitation Sciences, Katholieke Universiteit Leuven, Belgium
}

The aim of this study is to investigate athletic identity, self-esteem and physical self-perceptions in Flemish athletes with a disability, to investigate the mutual relationships between those variables, and to evaluate their stability over time. Flemish athletes (Paralympic level, $\mathrm{n}=23$; NonParalympic Elite level, $\mathrm{n}=37$ ) filled out questionnaires 11 months before the Paralympic Games (PG), 3 months before the PG, and immediately afterwards. Participants in both groups report strong levels of athletic identity, comparable to profiles in able-bodied sportive individuals. Similar findings are reported for global self-esteem and physical self-perceptions. With exception of physical confidence, no relationship was found between athletic identity and (physical) selfperceptions. Both athletic identity and (physical) self-perceptions are stable constructs over time.

Flemish athletes with disabilities possess a strong athletic identity and subsequent selfperceptions, in which they identify themselves with being 'real athletes'. This athletic identity is imbedded in a broad self-concept approach, largely independent from performances.

KEYWORDS: Athletic Identity, Disability Sport, Paralympics, Self-esteem, Physical Self-perceptions.

\section{INTRODUCTION}

There is accumulating evidence of the benefits of sports participation for individuals with disabilities. Regular exercise training has been shown to induce significant improvements in both cardiovascular and muscular fitness (e.g. Duran, Lugo, Ramirez, \& Eusse, 2001; Jacobs, Nash, \& Rusinowski, 2001; Hicks et al., 2003). In addition to the physiological benefits, also psychological benefits from sports participation accrued (e.g. Hanson \& Nabavi, 2001; Hutzler \& Bar-Eli, 1993; Manns \& Chadd, 1999; Sherrill, 1997).

Over the last 15 years, there is a growing belief that sport, properly conducted, provides opportunities for experiencing success and achievement and positive feelings about many aspects of self. Sports participation and competition can provide the ideal type of mastery challenge to help individuals stretch themselves far beyond the limitations that their disability may initially offer. Hutzler and BarEli (1993) and Campbell and Jones (1994) already summarized that (a) general improvements in self-esteem and athletic status result from sport participation, and (b) sport participants with disabilities have significantly higher self-esteem than inactive individuals with disabilities. Recently, Ferreira and Fox (2004) confirmed these findings in assessing physical self-esteem in wheelchair basketball players. Thus, it has been suggested that sport represents a potentially important avenue for the development of positive psychosocial characteristics (Martin, Adams-Mushett, \& Smith, 1995). This kind of information can help target individuals who may need increased social support during periods of injury or transitions out of sport (Martin et al., 1995).

The self-concept theory (Markus, 1977) provides a framework in which research regarding the value of sport for athletes with a disability can be conducted. The self-concept is viewed as a multidimensional construct of which different dimensions can be activated depending on the situation. This framework has led researchers to explore the relative salience of common dimensions, with athletic identity as an important component for many people (Brewer, Van Raalte, \& Linder, 1993). Within this framework, athletic identity is defined as the degree to which an individual

\footnotetext{
${ }^{1}$ Peter Van de Vliet is now with the International Paralympic Committee, Adenauerallee 212-214, 53113 Bonn, Germany. He was with the Department of Rehabilitation Sciences, Katholieke Universiteit Leuven, Belgium.
} 
identifies with the athlete role and looks to others for acknowledgement of that role (Brewer et al., 1993). According to previous work on able-bodied individuals, athletic identity has been shown to be related to health and physical fitness (Marsh, 1993), global selfesteem (Marsh, Perry, Horsely, \& Roche, 1995), improved social relationships and confidence (Petitpas, 1978) and participation in physical activity and exercise (Fox \& Corbin, 1989). Research in individuals with a disability has shown that: (a) higher levels of athletic identity could be found in individuals with spinal cord injury that engage in sports activities at regional, national or international level over individuals that do not regularly participate in sports activities (Tasiemski, Kennedy, Gardner, \& Blaikley, 2004); (b) adolescent swimmers with disabilities very much consider themselves athletes, but strong individual differences in self-perceptions of athletic identity can be found (Martin et al., 1995); and (c) athletic identity is a relevant and important component of self-concept among adolescent athletes with disabilities, but the self-schemas of many of those athletes are not limited solely to their athletic identity (Martin, Mushett, \& Eklund, 1994; Martin, Eklund, \& Mushett, 1997; Martin, 1999).

Athletic identity was examined based on the premise that sport-related benefits (i.c. physical self-efficacy, enhanced body image) would be manifested most strongly in athletes whose self-concepts were strongly tied into the athlete role (Martin, 1999). It is therefore not surprising that the findings related to athletic identity are in line with the findings of Hutzler and Bar-Eli (1993) regarding self-esteem in individuals with disabilities.

Based on these findings, athletic identity and its relationship to physical self-perceptions and self-esteem, are useful concepts for understanding sports participation in athletes with a disability. The overall purpose of the present paper was therefore to examine the perceptions of athletic identity and self-esteem in Flemish elite athletes with a disability. 'Elite' refers to the performance-based selection criterion those athletes meet to participate in international competitions. Three main research questions guided the present study: (a) What is the athletic identity and (physical) self-esteem profile of Flemish elite athletes with a disability compared to other individuals with a disability and to able-bodied athletes?; (b) How stable are the psychological profiles of Flemish athletes with a disability over time?; and (c) Is athletic identity related to (physical) self-esteem in Flemish elite athletes with disabilities?

\section{METHODS}

\section{Participants}

At the time of onset of data collection (October 2003), 60 Flemish athletes fulfilled the 'elite' standard for participation in international competition. This 'elite' criterion is a performance-based selection criterion, set by the National Paralympic Committee. Based upon current world rankings and world records, athletes are requested to obtain performances of at least $85-90 \%$ of the current world record (at least twice per season), or be in the first 1/3 of the current world ranking. A further distinction is then made between Elite A (>95\% of current world record, top 5 at world championships) and Elite B (those meet the 'elite' criterion, but not the Elite A standards).

A first sample in the present investigation consists of all Flemish speaking male Belgian athletes (further called 'Paralympic Athletes'), pre-selected for the 2004 Athens Paralympic Games $(n=23)$. These athletes not only fulfil the 'elite $A$ ' standard of the National Paralympic Committee, but also the criteria for participation at the Paralympic Games according the selection standards of the Athens Paralympic Organising Committee. During the period of data collection, 6 athletes got injured or did not succeed to fulfil the final selection criteria ( 1 additional perform-ance at 'elite A' level was asked from each individual athlete over the sport season 2003-2004), and 1 athlete who fulfilled the criteria twice during the sport season 2003-2004 was added to the group. The final sample of Paralympic athletes on which analyses are based consists of 18 athletes. They represent the following disability groups: cerebral palsy $(n=3)$, amputee $(n=3)$, paraplegic $(n=1)$, tetraplegic $(n=6)$, blind or 
visually impaired $(\mathrm{n}=1)$ and 'les autres' $(n=4)$. Paralympic athletes ranged in age from 17 to 48 years $(M=32.9, S D=8.2)$, and years of competitive experience ranged from 1 to 26 $(\mathrm{M}=13.8, \mathrm{SD}=7.2)$.

A second sample consists of the 'other' elite athletes $(n=37$; further called 'NonParalympic Elite Athletes'). In total, 28 (25 males, 3 females) participated in the present investigation. They represent the following disability groups: cerebral palsy $(\mathrm{n}=8)$, amputee $(n=4)$, paraplegic $(n=7)$, blind or visually impaired $(n=3)$ and les autres $(n=6)$.
They range in age from 13 to 25 years $(\mathrm{M}=18.6, \mathrm{SD}=3.0)$, with an average of 7.3 $(\mathrm{SD}=3.1$ ) years of experience (range: 2-13 years). Because some athletes did not participate in the present investigation over all three moments of data collection, data analyses is limited to 9 Non-Paralympic Elite Athletes that filled out all questionnaires at all data collection periods.

A flow chart with sample characteristics and spread over different sports is presented in Figure 1.

\section{Figure 1}

Flow chart of participant characteristics over the duration of the investigation [time $1=11$ months prior to 2004 Athens Paralympic Games (APG); time $2=2$ months prior to 2004 APG; time $3=1$ month after the 2004 APG] (upper part = Paralympic Athletes; bottom part = Non-Paralympic Elite Athletes; in circles $=$ total sample invited to participate; in box $=$ respondent characteristics)

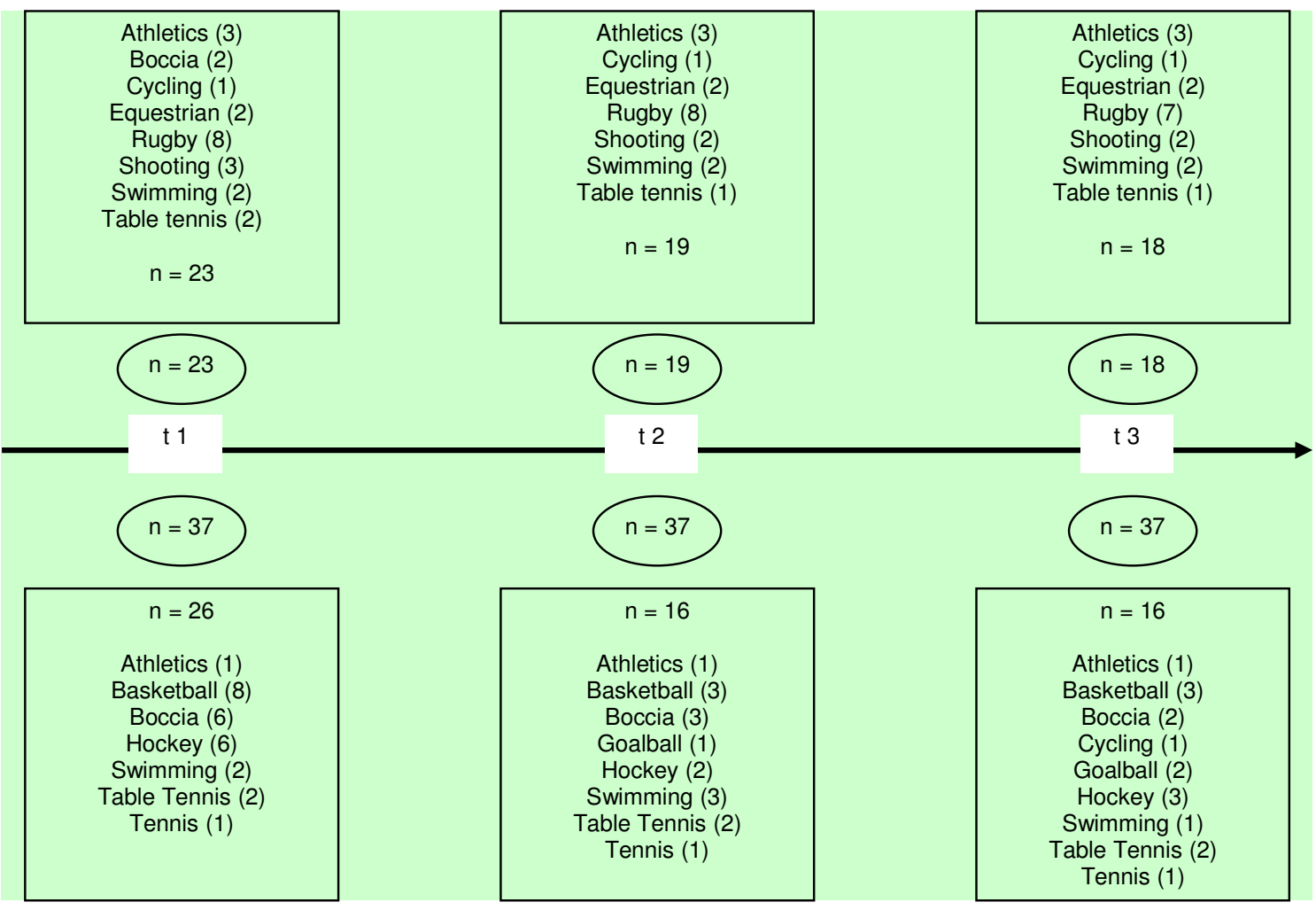




\section{INSTRUMENTS}

\section{Athletic Identity}

Athletic identity is measures by means of the translated version of the Athletic Identity Measurement Scale (AIMS, Brewer et al., 1993). The original AIMS consisted of 10 items. Subsequent research with athletes with disabilities revealed 9 items, loading on 4 subscales assessing self-identity (2 items, the degree to which the athlete identifies with the athletic role), social identity (2 items, the athlete's 'perception of others' to see him/her as an athlete), exclusivity (3 items, the degree to which athletes rely on their athletic profile compared to other roles such as friend, colleague, partner, ...); and negative affectivity ( 2 items, the degree of negative emotional response resulting from inability to train) (Martin, Mushett, \& Eklund, 1994). For each item, participants responded on a 7-point scale with 7 anchored by strongly agree and 1 anchored by strongly disagree. Test-retest reliability, international consistency and construct validity have been supported in research with swimmers with disabilities (Martin et al., 1994; 1997).

\section{Self-esteem}

Global self-esteem was assessed with the Dutch version of the Rosenberg Self-Esteem Inventory [RSE] (Helbing, 1982). The 10-item scale utilizes a 4-point Likert response format. The RSE is regarded a valid and reliable measurement of global self-esteem, which is also confirmed in Dutch populations (Helbing, 1982).

\section{Physical Self-perceptions}

The Dutch version of the Physical SelfPerception Profile [PSPP] (Van de Vliet, Knapen, Onghena, Fox, Van Coppenolle, David, Pieters, \& Peuskens, 2002) consists of three sub domain scales, whereas the initial PSPP (Fox \& Corbin, 1989) has 4 sub domain scales. Adequate reliability and validity for this 3 -subdomain PSPP in Flemish adult samples has been reported (Van de Vliet et al., 2002). The subscales are : perception of sports competence and physical condition (12 items, perceptions of sport and athletic ability and level of physical condition, ability to learn sport skills and to maintain exercise, and confidence in the sports environment, perceptions, stamina and exercise and fitness setting - Ferreira (2004) later renamed this sub domain scale in 'physical confidence'), perceived attractive body (6 items, perceived attractiveness of figure or physique, ability to maintain an attractive body and confidence in appearance), and perceived physical strength (6 items, perceived strength, muscle development, and confidence in situations requiring strength). An overall domain scale of physical self-worth (6 items, general feelings of happiness, satisfaction, pride, respect, and confidence in the physical self) completes the PSPP. Each item is presented in a four-point structured-alternative format, because of its record of reducing social desirable responding (Fox \& Corbin, 1989). The result is a response spread from 1 to 4 per item, with higher scores representing more positive perceptions.

\section{Procedures}

Data collection took place at three moments in time. Time 1 (onset of investigation) was in October 2003, 11 months prior to the 2004 Athens Paralympic Games. Time 2 was in June 2004 when the official selection for the Games was known (3 months prior to Games). Time 3 was 1 month after the end of the Games (October 2004).

The data of the Paralympic athletes have been collected during national training camps before the 2004 Athens Paralympic Games. Questionnaires were handed over to the athletes by the principal author. After the Games, the questionnaires were sent by regular mail with the request to return the completed questionnaires within 14 days. Master students reminded the participants to submit the completed questionnaires. The data of the NonParalympic Elite athletes have been collected through mailings with supplementary telephone calls by master students to receive completed questionnaires. If requested, assistance in filling out the questionnaires could be provided to both groups.

The Belgian Paralympic Committee agreed with the participation of their athletes in this study. The present investigation is limited to Flemish speaking athletes due to language 
requirements to complete the questionnaires. The athletes received a letter describing the purpose of the study, consent forms, a demographic questionnaire, and the athletic identity and (physical) self-esteem questionnaires.

\section{Statistical analyses}

Internal consistency of the different scales is assessed using Cronbach's alpha coefficients (Cronbach, 1951). Comparisons between samples are done using unpaired t-tests, on the basis of the data collected at time 1. Stability in time is assessed using Friedman one-way ANOVA for repeated measures, followed by post-hoc Tukey. The use of non-parametric statistics is motivated by the small sample size ( $\mathrm{n}=18$ and $\mathrm{n}=9$ respectively for the number of Paralympic and Elite athletes with all data at all times available). Correlations were calculated using Pearson product correlation analysis.

Since only 3 female athletes are included in the investigation (all within the 'elite' group), data were collapsed across gender for the analyses. All statistical analyses were performed using Statistica .6 (Statsoft, 2001), with an alpha 5\% significance level.

\section{RESULTS}

The purpose of the present study was to describe the athletic identity of Flemish athletes with a disability. A distinction is made between those athletes that were selected for the Paralympic Games in Athens ('Paralympic Athletes', $\mathrm{n}=23$ ) and those athletes that also met performance-related criteria to become 'elite' athlete ('Non-Paralympic Elite Athletes', $\mathrm{n}=37$ ). The performance-related criteria for this second group are a lower than for the Paralympic Athletes. These athletes also are younger $(\mathrm{t}=8.17, \mathrm{p}<.05)$ and less experienced $(\mathrm{t}=4.10, \mathrm{p}<.05)$. Because not all athletes expressed their willingness to participate in the present investigation, sample sizes differ over the three data collection period as indicated in Figure 1. Stability over time could be assessed for 18 Paralympic Athletes and 9 NonParalympic Elite Athletes.
All Cronbach alpha coefficients are .83 or more, except for global self-esteem $(\alpha=.70$ for Paralympic athletes; $\alpha=.67$ for NonParalympic Elite athletes), demonstrating acceptable to high internal consistencies.

As indicated in Table 1, both Flemish Paralympic and Non-Paralympic Elite athletes score high for athletic identity compared to other disabled and able-bodied athletes, reporting values similar to those of able-bodied university football players. In comparison to adolescent swimmers with a disability, the current high scores mainly can be contributed to a strong self- identity and exclusivity.

With regard to global self-esteem (Table 2), Flemish athletes also report significantly higher scores for global self-esteem compared to other disabled athletes. Again those values are in a similar range as those of able-bodied populations. Flemish Non-Paralympic elite athletes show a significantly higher global selfesteem than Flemish Paralympic athletes.

Regarding physical self-perceptions (Table 2), Flemish athletes with a disability achieve comparable high levels of physical self-worth and the respective sub domains compared to other disabled athletes and compared to ablebodied individuals. An exception needs to be made for perceived physical confidence in which athletes with a disability score higher than non-active able-bodied individuals. On the other hand, Portuguese wheelchair basketball players report higher perceived strength values compared to Flemish athletes with a disability.

Except for exclusivity in the group of Flemish Non-Paralympic elite athletes, athletic identity as well as self-esteem and physical self-perceptions seem to be stable constructs over time (Table 3).

Besides the relationships between subscales of the different instruments, an examination of all correlations (Table 4) reveals a significant relationship between physical confidence and athletic identity in Paralympic $(\mathrm{r}=.54)$ and Non-Paralympic Elite $(\mathrm{r}=.46)$ athletes, and between physical confidence and self-identity $(\mathrm{r}=.56)$ and social identity $(r=.42)$ in Non-Paralympic Elite athletes. 
Table 1

Athletic identity in Flemish Paralympic and Non-Paralympic elite athletes in comparison to other athletes with a disability and able-bodied athletes and non-active individuals [comparisons made at time 1, 11 months prior to Paralympic Games]

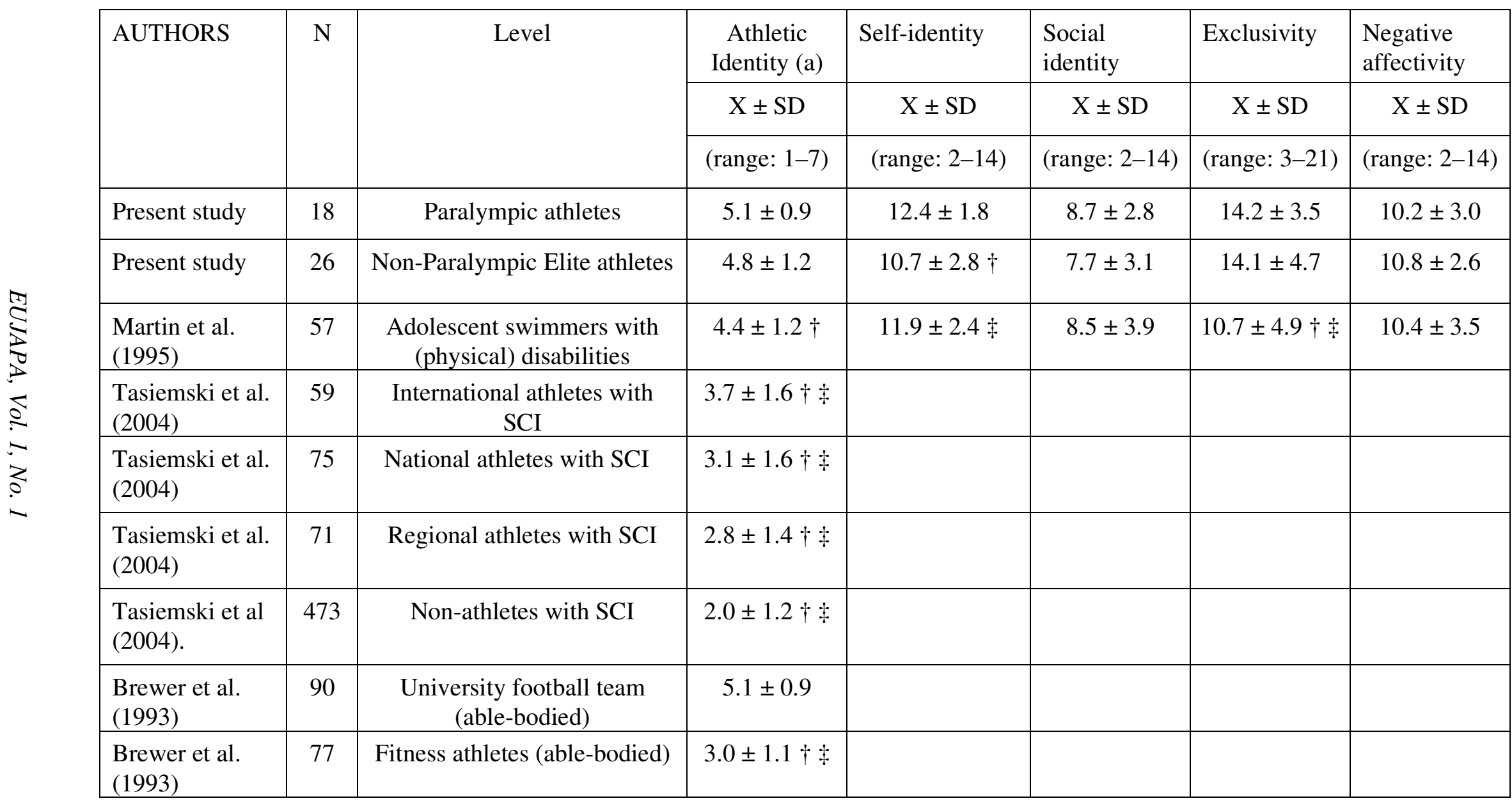

(a) divided by number of items for reasons of comparison between groups

$\dagger$ : significantly different from present study, Paralympic athletes $(\mathrm{p}<0.05)$

$\$$ : significantly different from present study, Non-Paralympic Elite athletes $(\mathrm{p}<0.05)$ 


\section{Table 2}

Self-esteem and (physical) self-perceptions in Flemish Paralympic and Non-Paralympic Elite athletes in comparison to other athletes with a disability and able-bodied individuals [comparisons made at time 1, 11 months prior to Paralympic Games]

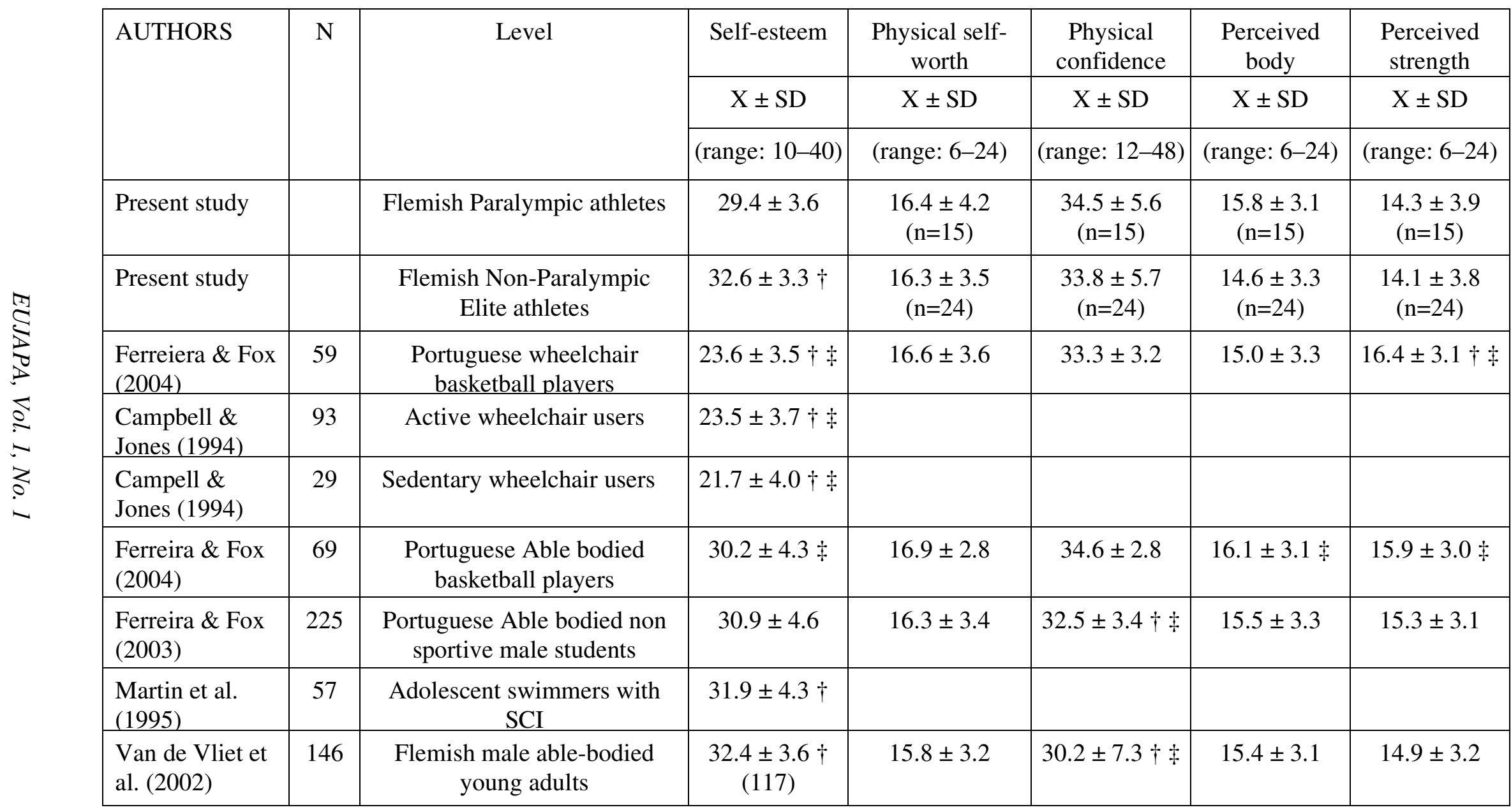

$\dagger$ : significantly different from present study, Paralympic athletes $(\mathrm{p}<0.05)$

\$: significantly different from present study, Non-Paralympic Elite athletes $(\mathrm{p}<0.05)$ 
Table 3

Stability of athletic identity and (physical) self-esteem over time in Flemish Paralympic and NonParalympic Elite athletes with a disability [time $1=11$ months prior to 2004 Athens Paralympic Games (APG); time $2=2$ months prior to 2004 APG; time $3=1$ month after the 2004 APG]

\begin{tabular}{|l|c|c|c|c|}
\cline { 2 - 5 } \multicolumn{1}{c|}{} & Time 1 & Time 2 & Time 3 & $\begin{array}{c}\text { Friedman } \\
\mathrm{X}^{2}\end{array}$ \\
\hline Flemish Paralympic & $\mathrm{X} \pm \mathrm{SD}$ & $\mathrm{X} \pm \mathrm{SD}$ & $\mathrm{X} \pm \mathrm{SD}$ & \\
\hline Athletes (n=18) & & & & \\
\hline Athletic identity & $46.1 \pm 7.9$ & $45.9 \pm 8.8$ & $45.1 \pm 8.3$ & 0.4 \\
Self-identity & $12.4 \pm 1.8$ & $12.1 \pm 2.8$ & $12.4 \pm 2.0$ & 0.3 \\
Social identity & $8.7 \pm 2.8$ & $8.1 \pm 2.1$ & $8.2 \pm 2.6$ & 1.7 \\
Exclusivity & $14.2 \pm 3.5$ & $15.2 \pm 3.8$ & $14.1 \pm 3.7$ & 2.9 \\
Negative affectivity & $10.2 \pm 3.0$ & $9.82 \pm 2.9$ & $10.2 \pm 2.7$ & 0.4 \\
Self-esteem & $29.4 \pm 3.6$ & $31.5 \pm 2.4$ & $31.6 \pm 3.1$ & 1.7 \\
Physical self-worth & $16.4 \pm 4.2$ & $16.1 \pm 2.8$ & $16.7 \pm 2.9$ & 3.0 \\
Physical confidence & $34.5 \pm 5.6$ & $36.6 \pm 3.0$ & $35.9 \pm 4.7$ & 0.001 \\
Perceived body & $15.8 \pm 3.1$ & $16.1 \pm 2.2$ & $16.4 \pm 2.9$ & 1.7 \\
Perceived strength & $14.3 \pm 3.9$ & $16.3 \pm 3.0$ & $16.8 \pm 3.6$ & 2.7 \\
\hline Flemish Non-Paralympic & & & & \\
Elite athletes (n=9) & 14.9 & 16.7 & \\
\hline Athletic identity & $43.3 \pm 10.4$ & $39.2 \pm 11.0$ & $38.0 \pm 10.5$ & 3.6 \\
Self-identity & $10.7 \pm 2.8$ & $10.4 \pm 3.0$ & $10.7 \pm 2.7$ & 1.3 \\
Social identity & $7.7 \pm 3.1$ & $7.3 \pm 2.6$ & $6.9 \pm 3.1$ & 1.2 \\
Exclusivity & $14.1 \pm 4.7$ & $10.8 \pm 5.2$ & $11.4 \pm 4.6$ & $6.4 *$ \\
Negative affectivity & $10.8 \pm 2.6$ & $10.7 \pm 2.9$ & $9.0 \pm 3.4$ & 2.9 \\
Self-esteem & $32.6 \pm 3.3$ & $31.9 \pm 4.6$ & $32.8 \pm 4.4$ & 0.4 \\
Physical self-worth & $16.3 \pm 3.5$ & $17.1 \pm 4.3$ & $16.7 \pm 4.3$ & 4.5 \\
Physical confidence & $33.8 \pm 5.7$ & $35.0 \pm 5.4$ & $35.4 \pm 5.2$ & 1.0 \\
Perceived body & $14.6 \pm 3.3$ & $16.0 \pm 3.0$ & $14.0 \pm 3.9$ & 3.0 \\
Perceived strength & $14.1 \pm 3.8$ & $15.0 \pm 3.4$ & $16.7 \pm 4.3$ & 0.2 \\
\hline
\end{tabular}

$* \mathrm{p}<0.05$ 
Table 4

Pairwise correlations between atletic identity, global self-esteem and physical self-perceptions in Flemish Paralympic athletes (upper right part of the table) and Flemish Elite athletes (bottom left part of the table) [comparisons made at time 1, 11 months prior to Paralympic Games]

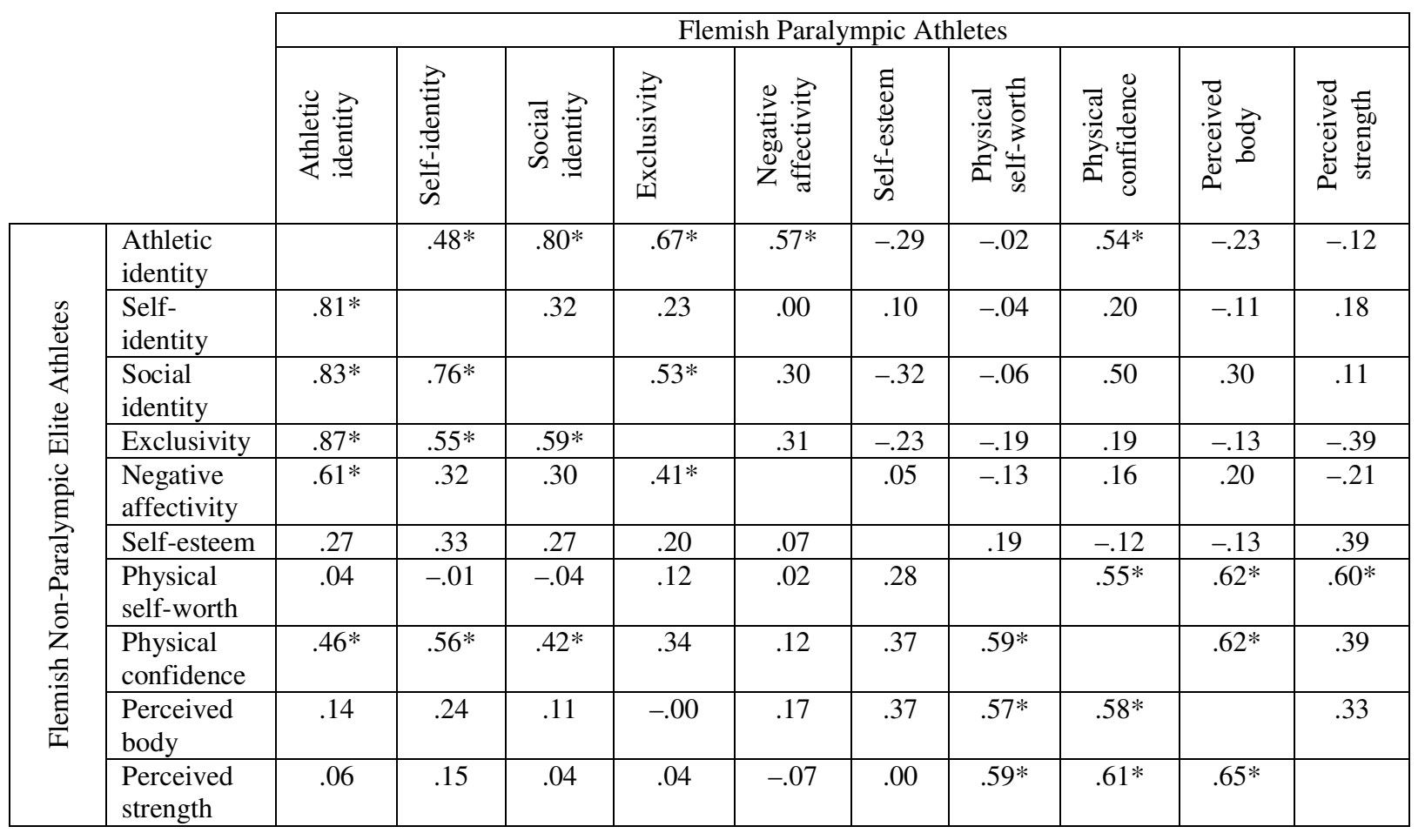

$* \mathrm{p}<0.05$

\section{DISCUSSION}

The purpose of the present study was to describe the athletic identity of Flemish athletes with a disability in comparison to other disabled athletes and able-bodied athletes. Because of the small sample sizes, related to the limited number of Flemish Paralympic and Non-Paralympic Elite athletes that meet those criteria, one is not allowed to draw firm conclusions. A response rate of $81 \%$ in the initial phase of data collection, however, can be considered very high. Another comment can be made with regard to the inclusion of 3 female ('Non-Paralympic Elite') athletes in the present investigation, although Martin et al. (1995) reports no gender differences for athletic identity in adolescent swimmers with disabilities. Furthermore, the groups lack homogeneity in terms of disability. Sherrill (1997) cautions against generalization over types of disability. However, it reflects what occurs in the applied setting, and small sample sizes in each category do not allow us to further subdivide the samples. As such, the nature of this investigation is explorative, but of utmost interest to further understand the personal profiles of athletes with a disability, and to counter the argument raised by Martin et al. (1994) that many 'others' do not consider athletes with disabilities as legitimate or real athletes.

First, the findings regarding athletic identity suggest that Flemish athletes with a disability do see themselves within the athlete role as much as able-bodied athletes do. Flemish Paralympic athletes report higher athletic identities compared to other national and international athletes with a disability. The mean scores for athletic identity are comparable to scores of competitive collegeaged athletes without a disability. These findings also account for Flemish Non- 
Paralympic Elite athletes, also fulfilling the performance-related selection criterion for international competition, but not selected as Paralympic athlete. Furthermore, some of the Non-Paralympic elite athletes already participate, in absence of a national competition, for a certain number of years in the international competitive circuit. Tasiemski et al. (2004) showed that this indeed might lead to higher levels of athletic identity. However, the data also suggest strong individual differences in self-perceptions in those, significantly younger and less experienced athletes.

An examination of subscales of the AIMS highlights a significant difference in selfidentity between the Paralympic athletes and Non-Paralympic Elite athletes in the present investigation. Paralympic athletes also consider themselves much more athletes with more goals solely related to sport. This is not surprising, since they participate at the highest level of competition (The "Games"). This leads to the recognition as 'being an athlete' and this athlete status, based on sporting achievement, is associated with athletic identity (Brewer \& Cornelius, 2001; Tasiemski et al., 2004). The ultimate "Games" goal made them bring offers in professional, personal and family life. The younger 'Non-Paralympic Elite' athletes, nor the adolescent swimmers in the Martin et al. (1995) investigation, did yet experience this challenge.

The concept that individuals with disabilities do not necessarily perceive their conditions and identities as bad, tragic, or negative is supported by the present findings. This is in line with the findings of Hutzler and Bar-Eli (1993) that sports participation has a beneficial effect on self-esteem, and with Sherrill (1997) who states that the disablement is not necessarily the major determinant of selfesteem for individuals with disabilities.

The presence of a significant relationship between athletic identity and self-esteem, reported in other investigations (e.g. Marsh, 1993) could not be confirmed in the present study. According Tasiemski et al. (2004) this could be due to the notion that individuals with disabilities rely on a broader self-concept, independent of sports participation being an integral part of their lives. As such, the development of an athletic identity in individuals with disabilities does not necessarily include a restrictive development of a multidimensional self-concept (athletes have self-schemas solely related to their athletic identities), which is often said to be the case (Brewer, 1993; Murphy, Petitpas, \& Brewer, 1996). Indeed, similar (adequate) levels of selfesteem and physical self-perceptions are reported in the Flemish athletes with a disability, compared to able-bodied peers. The significantly higher self-esteem value for the Non-Paralympic Elite athletes over the Paralympic athletes in the present study might be explained by the more 'black and white' thinking younger individuals might be engaged to (Tasiemski et al., 2004).

Strength of athletic identity is thought to vary with past and current athletic experience and the relative success or failure in this domain (Horton \& Mack, 2000). In the present investigation, however, athletic identity as well as self-esteem and physical self-perceptions seem to be very stable constructs, not explicitly related to the results in competition. Certainly in the 'Paralympic athlete' group, one might have expected that athletic identity would largely be related to the outcome of the Games. This does not seem to be the case, which is in agreement with Fliess-Douer, Hutlzer and Vanlandewijck (2003), and Sherrill (1998) who stated that talented athletes, including those with a disability, are mainly task-oriented. Not the medal, but the best performance seems to be the goal. This view seems to be supported by the analysis of the data of the 'NonParalympic Elite athletes', not selected for the Paralympic Games. Except for negative affectivity, athletic identity and selfperceptions also seem to be stable constructs. In this group, the assessments were not related to being (pre)selected or not (time $1 \& 2$ ) or 'how did I perform at the Games?' (time 3). It therefore seems that the intrinsic motivation of the individual athlete should be considered as the main factor to define athletic identity. Detailed analysis of the individual scoring profiles, however, again shows a large inter- 
individual variability over time. Further research should therefore include the assessment of motivational strategies, related to performance-related criteria, as well as an indepth investigation of the individual definition of 'being an athlete'. In the present investigation, all participants included are defined 'athletes' because they meet certain performance-related criteria. This approach does not bring into consideration the psychological nor personal profiles of the athletes.

In summary, the present study documents a strong athletic identity in Flemish athletes with a disability, not primarily oriented towards medals and records. These results support the importance of sports regarding increased awareness and acceptance of athletes with disabilities by themselves and by others. As a consequence, families, coaches, federation staff, and all related others should be aware that the athletes indicate that they invested a lot in their sport. Martin et al. (1995) mention that, as a consequence, one should acknowledge these athletes and continue to provide them challenging, competitive opportunities for athletic experience. The results of this study may further our understanding of psychological benefits of sports participation.

\section{ACKNOWLEDGEMENTS}

Special thanks to all the athletes who took part in the study; and to the students Kristel Breyne, Virginie Depuydt and Sara Van Bragt for collecting data.

\section{REFERENCES}

Brewer, B. W. (1993). Self-identity and specific vulnerability to depressed mood. Journal of Personality, 61, 69-77.

Brewer, B. W., \& Cornelius, A. E. (2001). Norms and factorial invariance of the Athletic Identity Measurement Scale. Academic Athletic Journal, 15, 103-113.

Brewer, B. W., Van Raalte, J. L., \& Linder, D. E. (1993). Athletic identity: Hercules' muscles or Achilles heel? International Journal of Sport Psychology, 24, 237-254.

Campbell E., \& Jones G. (1994). Psychological well-being in wheelchair sport participants and nonparticipants. Adapted Physical Activity Quarterly, 11, 404-415.

Cronbach, L. J. (1951). Coefficient alpha and the internal structure of tests. Psychometrika, 16, 297-334.

Duran, F. S., Lugo, L., Ramirez, L., \& Eusse, E. (2001). Effects of an exercise program on the rehabilitation of patients with spinal cord injury. Archives of Physical Medicine and Rehabilitation, 82, 1349-1354.

Ferreira, J. P. L. (2004). Physical selfperceptions in wheelchair sport participants. Unpublished doctoral thesis, Faculty of Social Sciences and Law, University of Bristol.

Ferreira J. P., \& Fox K. R. (2004). Selfperceptions and exercise in groups with special needs: Preliminary analyses, Physical activity and promotion of mental health: Proceedings of the First International Symposium of Exercise and Health Psychology (pp. 33-40). Coimbra (PT): Universidade de Coimbra.

Fliess-Douer, O., Hutlzer, Y., \& Vanlandewijck, Y. (2003). Relation of functional physical impairment and goal perspectives of wheelchair basketball players. Perceptual and Motor Skills, 96, 755-758.

Fox, K. R., \& Corbin C.B. (1989). The physical self-perception profile: Development and preliminary validation. Journal of Sport and Exercise Psychology, 11, 408-430.

Hanson, C., \& Nabavi, I. (2001). The effects of sports on level of community integration as reported by persons with spinal cord injury. American Journal of Occupational Therapy, 55, 332-338.

Helbing, J. C. (1982). Zelfwaardering: Meting en validiteit [Self-esteem: Measurement and validity]. Nederlands tijdschrift voor de Psychologie, 11, 257-277.

Hicks, A. L., Martin, K. A., Ditor, D. S., Latimer, A. E., Craven, C., \& Bugaresti, J. (2003). Long-term exercise training in persons with spinal cord injury: Effects on strength, arm ergometry performance and 
psychological well-being. Spinal Cord, 41, 34-43.

Horton, R. S., \& Mack, D. E. (2000). Athletic identity in marathon runners: Functional focus or dysfunctional commitment? Journal of Sport Behaviour, 23, 101-120.

Hutzler, Y., \& Bar-Eli, M. (1993). Psychological benefits of sports for disabled people: A review. Scandinavian Journal of Medical Science and Sports, 3, 217-228.

Jacobs, P. L., Nash, M. S., \& Rusinowski, J. W. (2001). Circuit training provides cardiorespiratory and strength benefits in persons with paraplegia. Medicine and Science in Sports and Exercise, 33, 711-717.

Manns, P. J., \& Chadd, K. E. (1999). Determining the relation between quality of life, handicap, fitness, and physical activity for persons with a spinal cord injury. Archives of Physical Medicine and Rehabilitation, 80, 1566-1571.

Markus, H. (1977). Self-schemata and processing information about the self. Journal of Personality and Social Psychology, 35, 63-78.

Marsh, H. W. (1993). Physical fitness selfconcept: Relations of physical fitness to field and technical indicators for boy and girls aged 9-25. Journal of Sport and Exercise Psychology, 15, 184-206.

Marsh, H. W., Perry, C., Horsely, C., \& Roche, L. (1995). Multidimensional self-concepts of elite athletes: How do they differ from the general population? Journal of Sport and Exercise Psychology, 17, 70-83.

Martin, J. J. (1999). Predictors of social physique anxiety in adolescent swimmers with physical disabilities. Adapted Physical Activity Quarterly, 16, 75-85.

Martin, J. J., Adams-Mushett, C., \& Smith, K. L. (1995). Athletic identity and sport orientation of adolescent swimmers with disabilities. Adapted Physical Activity Quarterly, 14, 113-123.

Martin, J. J., Eklund, R. C., \& Mushett, C. A. (1997). Factor structure of the Athletic Identity Measurement Scale with athletes with disabilities. Adapted Physical Activity Quarterly, 14, 74-82.
Martin, J. J., Mushett, C. A., \& Eklund, R. (1994). Factor structure of the Athletic Identity Measurement Scale with adolescent swimmers with disabilities. Brazilian International Journal of Adapted Physical Education research, 1, 87-99.

Murhpy, G. M., Petitpas, A. J., \& Brewer, B. W. (1996). Identity, foreclosure, athletic identity, and career maturity in intercollegiate athletes. The Sport Psychologist, 10, 239246.

Petitpas, A. J. (1978). Identity foreclosure: A unique challenge. Personnel and Guidance Journal, 56, 558-561.

Sherrill, C. (1997). Disability, identity, and involvement in sport and exercise. In K. R. Fox (Ed.), The physical self: From motivation to well-being (pp. 257-286). Champaign, IL: Human Kinetics.

Sherrill, C. (1998). Adapted physical activity, recreation and sport: Crossdisciplinary and lifespan. Boston: McGraw-Hill.

Statsoft, Inc. (2001). Statistica .6 (data analysis software system), version 6. www.statsoft.com

Tasiemski, T., Kennedy, P., Gardner, B. P., \& Blaikley R. A. (2004). Athletic identity and sports participation in people with spinal cord injury. Adapted Physical Activity Quarterly, 21, 364-378.

Van de Vliet, P., Knapen, J., Onghena, P., Fox, K. R., Van Coppenolle, H., David, A., Pieters, G., \& Peuskens, J. (2002). Assessment of physical self-perceptions in normal Flemish adults versus depressed psychiatric patients. Personality and Individual Differences, 32, 855-863.

Corresponding author's e-mail address: yves.vanlandewijck@faber.kuleuven.be 


\title{
SPORTLICHE IDENTITÄT UND SELBSTWERTGEFÜHL FLÄMISCHER ATHLETEN MIT BEHINDERUNG
}

\author{
(Resümee)
}

Das Ziel dieser Studie ist es sportliche Identität, Selbstwertgefühl und körperliche Selbstwahrnehmung bei flämischen Athleten mit Behinderung sowie die Wechselbeziehung zwischen den genannten Größen und deren Stabilität über die Zeit zu untersuchen. Die flämischen Athleten (paralympisches Level, $\mathrm{n}=23$; nicht paralympisches Elite-Level, $\mathrm{n}=37$ ) füllten Fragenbögen zu 3 Messpunkten aus: elf Monate vor den Paralympischen Spielen (POS), drei Monate vor den POS sowie unmittelbar nachher. Teilnehmer/innen in beiden Gruppen berichten von hoher sportlicher Identität, vergleichbar mit Profilen nichtbehinderter Sportler/innen. Ähnliche Ergebnisse ergaben sich beim generellen Selbstkonzept und für die physische Selbstwahrnehmung. Mit Ausnahme des körperlichen Zutrauens wurde keine Relation zwischen sportlicher Identität und (physischem) Selbstkonzept gefunden. Sowohl sportliche Identität als auch (physisches) Selbstkonzept sind stabile Konstrukte über die Zeit. Die flämischen Athleten mit Behinderungen besaßen eine starke sportliche Identität und eine daraus resultierende Selbsteinschätzung, mit der sie sich selbst als „echte" Athleten identifizierten. Diese sportliche Identität ist in einem breiten Selbstkonzept eingebettet, das von der Leistung weitgehend unabhängig zu sein scheint.

SCHLÜSSELWÖRTER: Sportliche Identität, Behindertensport, Paralympics, Selbstein-schätzung, physisches Selbstkonzept.

\section{IDENTITE ATHLETIQUE ET ESTIME DE SOI CHEZ LES ATHLETES FLAMANDS EN SITUATION DE HANDICAP}

(Résumé)

L'objectif de cette étude est d'enquêter sur l'identité athlétique, l'estime de soi et la perception physique de soi chez les athlètes flamands en situation de handicap, d'enquêter sur les relations entre ces variables et d'évaluer leur stabilité au cours du temps. Les athlètes flamands (niveau Paralympique, $\mathrm{n}=23$; niveau élite non Paralympique, $\mathrm{n}=37$ ) ont rempli des questionnaires 11 mois avant les Jeux Paralympiques (JP), 3 mois avant les JP et immédiatement après l'événement. Concernant l'identité athlétique, des participants des deux groupes présentent des résultats élevés comparables aux profils des sportifs individuels valides. Des résultats similaires ont été obtenus concernant l'estime de soi d'une manière générale. A l'exception de la confiance physique, aucune relation n'a été trouvée entre l'identité athlétique et la perception (physique) de soi. Ces deux dernières variables sont stables au cours du temps. Les athlètes flamands en situation de handicap possèdent une forte identité athlétique et une perception d'eux-mêmes subséquente dans laquelle ils s'identifient en tant que «réels athlètes ». Cette identité athlétique est ancrée dans une approche étendue du concept de soi, indépendante des performances.

MOTS CLEFS: Identité athlétique, Handicap, Sport, Paralympique, Estime de soi, Perception physique de soi. 